\title{
OBLIQUE ALAMO BOLIDE IMPACT? EXCEPTIONAL ALAMO BRECCIA PRESERVATION AT DEVILS GATE LS TYPE SECTION, \\ Alamo Impact Info and Assumptions \\ EAST CENTRAL NEVADA
}

$1 \mathrm{~km}$ sized icy cometary impacted Paleozoic Miogeocline near shelf-slope boundary $\sim 300$ meter water depth Middle Frasnian - medial Punctata Conodont zone $\pm \mathbf{3 7 8}$ mya - (older guesses range from 382 to 362 ) Impact effects documented in $400 \mathrm{~km}$ diameter: Utah, California, Las Vegas Alamo 'Member' stratigraphy is radial zoning Unit A = Tsunamiite(s) redeposited widespread impact breccia- outer zones Unit B = Impact Breccia ejecta - not present 'distally'inner zones Unit $\mathrm{C}=\mathrm{Co}-$ herent slide blocks 'floating' in Breccia in Ring Zone backfill - inner zones

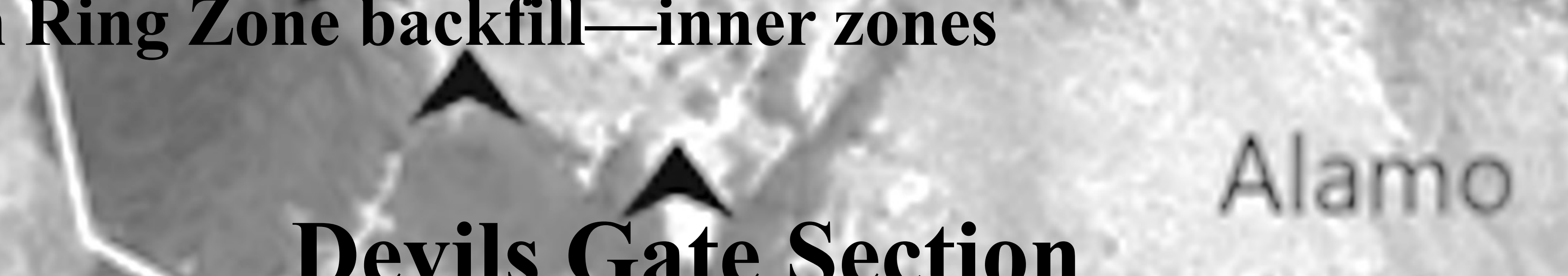

\section{Devils Gate Section}

Devils Gate $\sim 210 \mathrm{~km}$ from impact centroid Shelfal - lagoonal low productivity variably salinity carbonate environment as ejecta fell from the sky Alamo Breccia Member: Units A \& B are both present - unique at this Adist. Unit $A=29 \mathrm{~cm}$ graded calc granule-arenite(?s) Ir anomaly $>$ Inner zones. Shocked qtz \& hematite studs Unit $B=$ Calc diamictite $\sim 0.5$ to 1.4 meters Contact with A is 'wavy': standing wave flow structure?

\section{Oblique Impacts}

$<0^{\circ}$ Angle of incidence produces asymmetric crater \& impact deposits move away from isotropic ray model (Tycho)

$<15^{\circ}$ Produces elliptical crater \& Butterfly impact ejecta blanket symmetrically

No-ejecta zones both down and up-range. Ejecta to sides.

\section{Speculation}

Unit B not normal part of Distal Zone 3/Runup Realm model Presence not consistent with orthogonal impact model

Alamo overall ejecta and structure is half-oval/ellipse Perhaps an oblique impact better explains?

DG Alamo Member would be pat of the butterfly ejecta pattern

\section{beds The Argument}

1. Impact breccia reached Devils Gate as an anisotropic blanket

2. Consistent with oval/elliptical structure of entire Alamo

3. Megatsunamis longitudinally traversed $\sim 125 \mathrm{KM}$ of the shallow shelf losing erosive energy maybe partially eroding the top DG breccia

4. Multiple tsunamis removed thin ejecta blanket everywhere else

5. Final Unit A Tsunamiite(s) preserved above a wavy contact, suggesting mild flow dynamics, with ejecta Unit B remnant. 